Матухно О.В., Бєлоконь К.В., Баранова Т.Є., Романько Я.В.

Удосконалення екологічної компоненти сталого розвитку металургійних підприсмств шляхом впровадження найкращих доступних технологій Matukhno E., Belokon K., Baranova T., Romanko Y.

\title{
Improving the environmental component of sustainable development of metallurgical enterprises through the implementation of the best available technologies
}

\begin{abstract}
Метою роботи є наукове обгрунтування напрямків вдосконалення екологічної компоненти сталого розвитку підприємств металургійного комплексу шляхом впровадження найкращих доступних технологій. Методика. Теоретичною і методичною основою дослідження є вітчизняні та зарубіжні публікації з питань сталого розвитку, нормативні та рекомендаційні документи, результати екологічних аудитів, що проводились авторами роботи на вітчизняних підприємствах. У роботі застосовані наступні методи досліджень: аналіз, синтез, класифрікація, порівняння, узагальнення.

Результати. В роботі уточнено зміст екологічного аспекту поняття «сталий розвиток промислового підприємства». Виявлено та систематизовано фрактори, що впливають на екологічні показники сталого розвитку металургійного комплексу України. Охарактеризовано екологічні пріоритети в розвитку вітчизняних промислових підприємств. Обгрунтовано доцільність застосування найкращих доступних технологій на підприємствах металургійного комплексу для зниження енергоспоживання i зменшення забруднення навколишнього середовища. Представлено посилання на нормативні документи України, що містять вимоги щодо використання найкращих доступних технологій у виробництві.

Надано аналіз результатів, одержаних авторами при проведені екологічних аудитів, а також наведених на сайтах ведучих вітчизняних заводів та підприємств, у сфрері застосування найкращих доступних технологій. Практична значимість. Запропоновано рекомендації щодо вдосконалення екологічної компоненти сталого розвитку підприємств металургійного комплексу. Виконання цих рекомендацій підвищить конкурентоспроможність підприємств і дозволить продукиії, що вироблена вітчизняною металургійною промисловістю, відповідати вимогам європейського та світового ринків.

Ключові слова: сталий розвиток, металургійні підприємства, екологічні аспекти, найкращі доступні технології

The objective and tasks of research of environmental aspects of sustained development of metallurgical enterprises were defined. Method. The objective of research is a scientific substantiation of directions of the improvement of the ecological component of sustained development of metallurgical enterprises based on the implementation of the best available technologies.

Domestic and foreign publications in the matters of sustained development, regulatory and recommendation documents, the results of environmental audits form the theoretical and methodological basis of the research. The following methods of the research are applied in the paper: analysis, synthesis, classification, comparison and generalization.

Results. Content of environmental aspect of the notion "sustained development of industrial enterprise" is specified. The factors influencing on the environmental aspects of sustained development of metallurgical enterprises are identified and classified. Environmental priorities in the development of domestic industrial enterprises are characterized. Reasonability of application of the best available technologies at the metallurgical enterprises for the purpose of energy usage reduction and reduction in environmental pollution is substantiated. References to regulatory documents of Ukraine including requirements to application of the best available technologies in production are provided.

The analysis of results obtained by the authors during conduct of environmental audits as well as presented on the websites of leading domestic plants and enterprises in the context of application of the best available technologies is provided. Practical significance. Recommendations on the improvement of the ecological component of sustained development of metallurgical enterprises are offered. Fulfillment of these recommendations would improve the competitive capacity of enterprises and would enable the compliance of products manufactured by metallurgical industry with the requirements of European and global market.

Keywords: sustainable development, metallurgical enterprises, environmental aspects, best available technologies
\end{abstract}

\section{Introduction.}

In the modern development of production, there is a need to overcome the contradiction between the level of technological process and environmental safety. Triple Bottom Line Model was proposed by Elkington (1997) as a means towards sustainable development that underpins most of the discourse and policy-making in fields such as economic development, environmental protection and sustainable society [1-2]. Sustainable manufacturing development

Матухно Олена Вікторівна - к.т.Н., доц. НМетАУ Бєлоконь Каріна Володимирівна - к.Т.Н.,доц. ЗНУ Баранова Тетяна Євгеніївна - асистент НМетАУ Романько Ярослав Вікторович - к.т.н., доц. НМетАУ.В. involves broadening the traditional economic outlook to include environmental and social considerations.

Analysis of literature data and problem statement.

Analysis of the matter of sustained development of industrial enterprises [3-6] made it clear that the researchers of these science topics in most cases consider the economic and financial aspects of this notion. So, for example, the paper [5] offers the ways of provision of sustained development of territories after dissolution of mining and extraction enterprises and 
during rehabilitation of territories; the strategy of management of enterprises based on "diversification of economic activity" was proposed. However, the authors neglected the environmental aspects of operating enterprise enabling to increase its competitive ability and "stability in the global market".

The paper [6] covers the matters of sustained development of industrial enterprises under the conditions of lack of energy resources; it focuses on the innovative solutions in the context of energy security of mining and extraction and processing companies. However, the matters of environmental safety in the context of sustained development of the enterprise were not considered.

The "Sustainability Reporting Guidelines" [4] and the series of academic papers [3, 7, 8] point out that the sustained development of the enterprise consists in the provision of high indicators of social, economic and environmental development of the region for a long time. So, the sustained development of regions and countries consisting in the improvement of the indicators of economic, social and environmental performance, and, consequently, the improvement of quality of life of the citizens is impossible without sustained development of enterprises.

Ecological component of sustained development of the enterprise is related to the influence of the enterprise on the natural systems, soils, atmosphere, hydrosphere, fauna and flora. The document [4, page 30] points out that the "environmental indicators reflect the results of activity related to input (for example, raw materials, energy, water) and output (for example, emissions, waste waters, waste) flows. Moreover, they reflect the results of the activity related to biodiversity and compliance with regulatory requirements, as well as other significant information, for example, expenditures related to the environment (investments), as well as impact of products and services of the organization" on the environment.

Since 2004 the range of socially responsible iron and steel companies report the indicators of their sustained development to the global community. In 2018, 97 steel-casting entities provided their data for the year 2017 [9]. These indicators reflect the key aspects of economic, environmental and social obligations stated in the policy of sustained development of enterprises and meet the purposes of sustained development of United Nations Organization. For example, environmental indicators: emissions greenhouse gases ( $\mathrm{t} \mathrm{CO}_{2} / \mathrm{t}$ of steel), energy capacity (GJ/t of steel), efficiency of utilization of raw materials and materials (\% of materials converted into final product and by-products), environment management system (\% of employees certified according to the international standard ISO 14001 or EMAS); social factors: lost time injury frequency (number of injuries per million exposure hours), personnel training (days of training of one employee per year); economic indicators: investments into new processes and products (\% from annual income), distributional economic value ( $\%$ from annual income). It should be pointed out that all listed environmental indicators are based on the implementation of the best available technologies.

Objective and problems of the research.

The objective of research is a scientific substantiation of directions of the improvement of the ecological component of sustained development of metallurgical enterprises based on the implementation of the best available technologies.

The following problems were formulated in the course of research:

to specify content of the notion "sustained development of industrial enterprise" in respect of the environmental aspect;

to identify and to classify the factors influencing on the ecological component of sustained development of metallurgical enterprises of Ukraine in the current context;

to offer directions of the improvement of the environmental aspect of the strategy of sustained development of industrial enterprises.

Materials and methods of research.

Domestic and foreign publications in the matters of sustained development, regulatory and recommendation documents form the theoretical and methodological basis of the research. The following methods of the research are applied in the paper: analysis, synthesis, classification, comparison and generalization.

Results of researches of environmental aspects of sustained development of metallurgical enterprises.

The experience of European countries has proven that in the environmental terms the sustained development of metallurgical enterprises is possible due to implementation of series of organizational and technical solutions, for example:

1. Switch from old methods (technologies) of production to new ones which make it possible:

to reduce the industrial influence on the environment (for example, from open-hearth steelmaking to oxygenous-converter or electric smelting);

to produce high-quality products;

to expand sales markets due to increase in the indicators of quality of products and green production.

2. Modernization of the basic equipment for the purpose of provision of the efficient operation of the enterprise and environmental impact reduction.

3. Switch to "clean" technologies and installation of high-efficient cleaning equipment.

4. Creation of closed water rotation cycles.

5. Strict control over raw materials. Usage of highquality raw materials complying with technical and environmental requirements enables to upgrade the quality of products and to improve the environmental indicators of engineering processes at the same time.

6. Energy- and resource-saving measures.

7. Maximal involvement of secondary material and energy resources transforming into own engineering processes in the course of production.

8. Advanced training of human resources of the enterprises.

9. Implementation of system of environmental and energy management. 
10. Active investments into environmental protection measures and equipment.

11. Creation of modern large industrial complexes with cyclical turnaround on the basis of preexistent enterprises with a limited number of process stages.

Six approaches $(1-4,6,7)$ from the presented list should be classified as "the best available technologies" (BAT). Analysis of scientific publications [8, 10] also has proven that provision of one of the factors of sustained development of industrial enterprises competitive ability - requires primarily the moderniza- tion of basic funds and implementation of advanced technologies.

The term of the best available technologies is explained in the EU directive [11] (fig. 1) specifying that EU member states should apply the best available technologies for the purpose of integrated environment pollution prevention and control in the variety of industrial sectors, in particular: energy, metal fabrication and working; mining and extraction; chemical; waste utilization; other kinds of production activity.

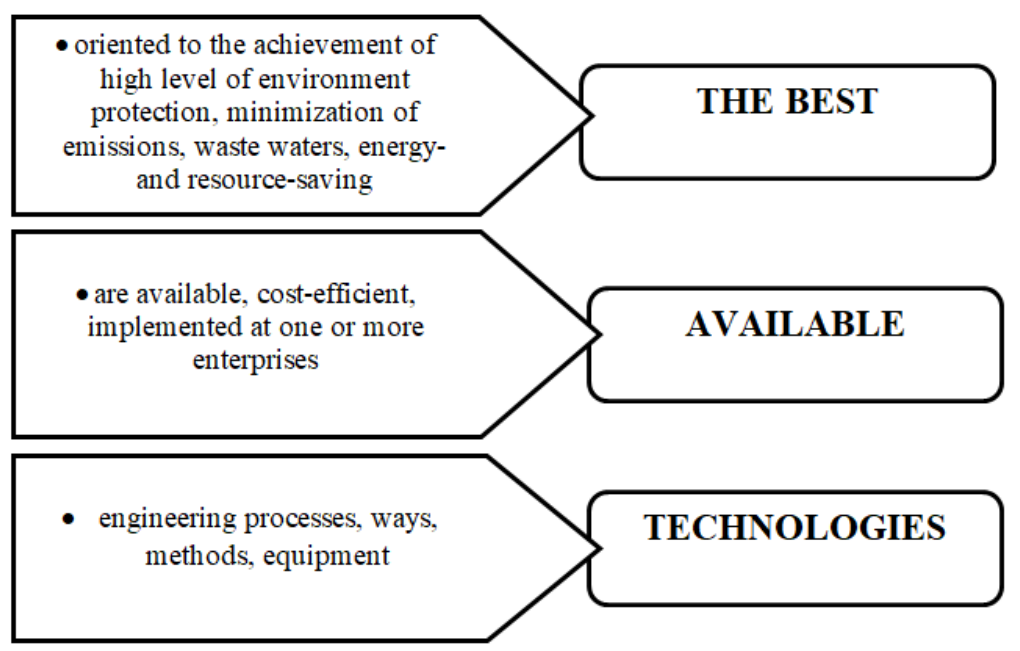

Fig. 1 The best available technologies

"The plan of measures on adherence to Association agreement between Ukraine, on the one part, and the European Union, European Atomic Energy Community and their member states, on the other part" [12] was approved by the Order of the Cabinet of Ministers of Ukraine no. 1106 dd. October 25, 2017 "On adherence to Association agreement between Ukraine, on the one part, and the European Union, European Atomic Energy Community and their member states, on the other part" resulting in the fact that the essential modernization of the production has to be carried out in our country with due regard to EU constant environmental impact reduction directive by means of application of the best available technologies.

Moreover, the series of regulatory documents of Ukraine use the term "the latest technologies" for a while; according to opinions of the authors this term is comparable to the term "the best available technologies". For example, the Act of Ukraine "On the natural environment protection" [13] and the Instruction "On the general requirements to execution of documents substantiating volumes of emissions for procurement of permits for emissions of pollutants into the atmospheric air by stationary sources for enterprises, institutions, organizations and citizens - entrepreneurs" (Order of the Ministry of nature of Ukraine no. $108 \mathrm{dd}$. March 09, 2006 [14] contains the requirements to application of the best available technologies (table 1)).
In spite of the above-listed requirements, the Ukrainian law currently does not require the application of the best available technologies from industrial enterprises during modernization and computer aided manufacturing. However, company's management team has to take into account that application of the best available technologies makes an integrated positive impact on the production in general and enables to improve not only the environmental indicators, but also the economic and social ones.

We would like to point out individually the importance of the matter of competitive ability of the products of mining and smelting enterprises under the conditions of severe competitive struggle at the sales markets. Economically the competitive ability of the products is one of the basic factors of business continuity of the enterprise. It is the ability of the manufacturer to keep the sales revenue for a long time during fluctuations of consumer demand on the market which is the characteristic of enterprise reliability [7].

New approaches to solution of the environmental matters based not only on the best engineering solutions but also on the series of regulatory documents ISO 14000, ISO 50000 etc. enable to achieve positive results in the provision of "smooth operation", high competitive ability and improvement of environmental safety of industrial enterprises. 
Table 1 Requirements to application of the best available technologies in the regulatory documents of Ukraine

\begin{tabular}{|c|c|c|}
\hline $\begin{array}{l}\text { Name of the doc- } \\
\text { ument }\end{array}$ & $\begin{array}{l}\text { Article, } \\
\text { chapter }\end{array}$ & Nam of the chapter / Requirement \\
\hline \multirow{2}{*}{$\begin{array}{l}\text { The Act of } \\
\text { Ukraine "On the } \\
\text { natural environ- } \\
\text { ment protection" }\end{array}$} & Article 3, clause "г" & $\begin{array}{l}\text { "ecologization of material production based on comprehen- } \\
\text { siveness of solutions in matters of natural environment pro- } \\
\text { tection, usage and reproduction of renewable natural re- } \\
\text { sources, large-scale implementation of the latest technolo- } \\
\text { gies" was referred to as one of the basic principles of the } \\
\text { environment protection }\end{array}$ \\
\hline & $\begin{array}{l}\text { Article } 40 . \text { clause } \\
\text { "a" }\end{array}$ & $\begin{array}{l}\text { "rational and economical use of natural resources based on } \\
\text { large-scale implementation of the latest technologies" was } \\
\text { defined as one of the compulsory environmental require- } \\
\text { ment }\end{array}$ \\
\hline \multirow{3}{*}{$\begin{array}{l}\text { The Instruction } \\
\text { "On the general } \\
\text { requirements to } \\
\text { execution of doc- } \\
\text { uments substanti- } \\
\text { ating volumes of } \\
\text { emissions for pro- } \\
\text { curement of per- } \\
\text { mits for emissions } \\
\text { of pollutants into } \\
\text { the atmospheric } \\
\text { air by stationary } \\
\text { sources for enter- } \\
\text { prises, institu- } \\
\text { tions, organiza- } \\
\text { tions and citizens } \\
\text { - entrepreneurs" }\end{array}$} & Supplement 3 & $\begin{array}{l}\text { "List of productions and processing equipment being sub- } \\
\text { ject to application of the best available technologies and } \\
\text { methods of control" }\end{array}$ \\
\hline & Supplement 7 & $\begin{array}{l}\text { type of reporting "Measures on the implementation of the } \\
\text { best existing technologies of production that do not require } \\
\text { excessive costs and the best available technologies and } \\
\text { methods of control" }\end{array}$ \\
\hline & Clause 2.11 & $\begin{array}{l}\text { The special aspects of implementation of the best available } \\
\text { technologies for preexisting and newly established facilities } \\
\text { were considered. It was pointed out that: } \\
\text { implementation of the best available technologies for preex- } \\
\text { isting facilities should not result in the excessive costs; } \\
\text { in the event of newly established facilities the best available } \\
\text { technologies apply under the conditions of economic and } \\
\text { technical reasonability, accessibility in the context of ex- } \\
\text { penditures, the greatest efficiency for the purpose of } \\
\text { achievement of the high level of environment protection in } \\
\text { general }\end{array}$ \\
\hline
\end{tabular}

"The principles of environmental management organization" are implemented the most intensively in the mining and smelting industry of Ukraine according to ISO 14001, 14004-14006 on the basis of which the corporate plans of "sustained development" of enterprises (so-called "corporate social responsibility") are developed. The efficiency of environmental management of the company consists in violation of directly proportional dependence "economic growth - environment pollution". So, the enterprise works towards the improvement of environmental indicators during simultaneous growth of products manufacturing. We can tell about "sustained development" of the enterprise under the conditions of the fulfillment of these terms.

It should be also taken into account during assessment of "reliability" of the enterprise that the international system of environmental certification based on ISO 14020, 14021, 14024, 14025 even today is one of the main criteria of competitive ability of marketable products at the global market. Environmental certification of metallurgical enterprises is one of the perspective ways of marketing development due to the fact that foreign consumer imposes strict requirements not only to the quality of acquirable product but also to its environmental characteristics. Production that has the environmental labeling or the ecological cleanness labeling is more competitive at the global market, its products are commercially successful and are priced higher.

Having regard to the above, the improvement of environmental indicators by the way of investments into the environmental projects upon experience of European countries and best achievements of national science and practice is currently topical for metallurgical enterprises.

Discussion of the results of research of environmental aspects of sustained development of the metallurgical enterprises.

Analysis of information obtained by the authors during conduct of environmental audits, as well data presented on the web-sites of leading domestic plants and enterprises with foreign investments (PrJSC "ArcelorMittal Kryvyi Rih", PJSC "Zaporizhstal", PrJSC "Dniprovskyi metallurgical plant") proves that the environmental aspects of last year's take into account the recommendations of environmental audits and are oriented to:

improvement of the condition of atmospheric air due to reduction of gross emissions of dust and gases during installation and upgrading of gas-handling equipment that enables to diminish gas pollution both from controlled and fugitive sources of emissions;

maximum water environment impact reduction due to creation of closed water rotation cycles; 
strict control of quantities of occurring solid wastes, arrangement of their utilization in own production, minimization of areas of territories occupied by the dumping sites;

development of social environment due to creation of new jobs with improved working conditions.

However, it should be pointed out that the most of the implemented measures and projects are the capital repairs or partial upgrading of existing purification and treatment facilities and equipment. In such a case the best available technologies are not applied usually in terms of environment protection. At the same time the series of enterprises carries out implementation of new technologies according to reference documents on the best available technologies (so-called BREF - BAT reference documents), for example, implementation of continuous -casting machines that reduce the negative impact of rolling-mill practice on the environment substantially.

Divisions (departments) of environmental management of leading iron and steel enterprises of Ukraine constantly work towards formation and improvement of "sustained development and smooth operation" of productions. However, they work insufficiently in comparison with enterprises of developed countries.

High relative indicators of emissions of pollutants into air, discharge of sewage waters and waste generation in comparison with European indicators (excess by 3-5 times) are the basic factors influencing on the ecological component of sustained development of the metallurgical enterprises of Ukraine resulting in deterioration of quality of atmosphere air, contamination of surface watercourses, expansion in the number of waste in the dumping sites, tailing dumps and other collectors at mining and smelting centers of Ukraine. In addition to negative impact on the environment all of this substantially slows down the pro- cess of decrease in self cost of final products, prevents from compliance with the dependence "reduction in the negative impact on the environment under simultaneous increase in performance" that is specifically the indicator of the sustained development of the enterprise.

Conclusions.

Metallurgical complex is a resource- and energyintensive; it is related to substantial negative impact on the environment exceeding relative indicators by 3-5 times in Ukraine in comparison with European indicators. Extraction of raw materials and steel consumption per head of populations grows constantly across the globe resulting in escalation of problem of environment pollution and requires proactive implementation of environment-geared projects and new technologies being more efficient on a number of indicators in comparison with existing ones. Finally, it will enable to diminish environment pollution during growth of volumes of production being the basis of the sustained development of enterprises.

Metallurgical production belong to the kinds of activity in which EU Directives recommend to apply the best available technologies for restriction of environment pollution and energy consumption.

Metallurgical enterprises of Ukraine are assigned with the task of modernization of existing enterprises according to the requirements of external and internal markets. Modernization has to be carried out with due regard to international experience and has to provide not only the prudent use of natural resources but also compliance with environmental regulations on the environment protection at the modern level.

Production of environmentally safe products under conditions of severe competition at the global sales markets should become the priority of development of all sectors of economy of Ukraine, including metallurgical enterprises.

\section{References}

1. Elkington J. Cannibals with Forks: The Triple Bottom Lines of 21st Century Business. Capstone Publishing, Oxford, 1999. 410 p. ISBN1841120847, 9781841120843.

2. Pankojini Mulia, Ajit Kumar Behura, Sarita Kar. Categorical Imperative in Defense of Strong Sustainability. Problemy Ekorozwoju - Problems of sustainable development. 2016. Vol. 11, № 2. P. 29-36. ISSN 1895-6912.

3. Sustainable Steel. Policy and indicators 2016. URL: https://www.worldsteel.org/en/dam/jcr:c2fc4379-e6dc-4631badb-8e7c41660b32/sustainable_steel_2016_vfinal.pdf_accessed:5.06.19).

4. Rukovodstvo po otchetnosti $\mathrm{v}$ oblasti ustoychivogo razvitiya. URL: http://rspp.ru/12/11938.pdf (accessed: 5.06.19).

5. Pivnyak H.H., Pilov P.I., Pashkevych M.S., Shashenko D.O. Synchro-mining: tsyvilizovane vyrishennya problemy staloho funktsionuvannya hirnychodobuvnykh rehioniv. Naukovyy visnyk Natsional'noho hirnychoho universytetu. 2012. № 3. S. 131-138. ISSN (print) 2071-2227, ISSN (online) 2223-2362, Scopus.

6. Bondar-Pidhurs'ka O. V. Naukovo-metodychni aspekty innovatsiynoho rozvytku hirnychodobuvnoyi promyslovosti v konteksti staloho zrostannya. Naukovyy visnyk Natsional'noho hirnychoho universytetu. 2014. № 1. S. 143152. ISSN (print) 2071-2227, ISSN (online) 2223-2362, Scopus.

7. Grishakov K. Ponyatie ustoychivogo razvitiya promyishlennogo predpriyatiya. SCI-ARTICLE.RU. 2013. № 3. URL: http://sci-article.ru/stat.php?i=ponyatie ustoychivogo razvitiya promyshlennogo predpriyatiya (accessed: 5.06.19).

8. Shatokha V.I., Semenko S.O. Analiz tendentsiy i perspektiv razvitiya mirovoy chernoy metallurgii s uchetom faktora izmeneniya klimata. Ekologiya i promyishlennost. 2015. №1. S. 10-14. ISSN 2311-584X.

9. Sustainability indicators. URL: https://www.worldsteel.org/steel-by-topic/sustainability/sustainabilityindicators.html (accessed: 5.06.19).

10. Shatokha V.I., Rogoza M.V. Stsenarii razvitiya chernoy metallurgii: mirovyie tendentsii i vyizov Ukrainyi. Management for sustainable development in transitional economies: monografi. Razdel 3. Potentsial ustoychivogo razvitiya proizvodstvennoy sferyi. Dnepropetrovsk-Cottbus. 2015. S. 141-152. ISBN 978-966-921-006-7. 
11. Directive 2010/75/EU of the European Parliament and of the Council of 24 November 2010 on industrial emissions (integrated pollution prevention and control). URL: https://eur-lex.europa.eu/eli/dir/2010/75/oj (accessed: 5.06 .19 ).

12. Postanovlenie Kabineta Ministrov Ukrainyi № 1106 ot 25.10 .2017 g. «Pro vykonannia Uhody pro asotsiatsiiu mizh Ukrainoiu, z odniiei storony, ta Yevropeiskym Soiuzom, Yevropeiskym spivtovarystvom z atomnoi enerhii i yikhnimy derzhavamy-chlenamy, z inshoi storony». URL: http://zakon.rada.gov.ua/laws/show/1106-2017\%D0\%BF\#n10 (accessed: 5.06.19).

13. Zakon Ukrayini Pro ohoronu navkolishnogo prirodnogo seredovischa. Vidomosti Verhovnoyi Radi Ukrayini (VVR). 1991. № 41. URL: http://zakon2.rada.gov.ua/laws/show/1264-12 (accessed: 5.06.19).

14. Nakaz N 108 vid 09.03.2006 pro zatverdzhennya instruktsiyi pro zagalni vimogi do oformlennya dokumentiv, u yakih obgruntovuyutsya obsyagi vikidiv, dlya otrimannya dozvolu na vikidi zabrudnyuyuchih rechovin $v$ atmosferne povitrya statsionarnimi dzherelami dlya pidpriemstv, ustanov, organizatsiy ta gromadyan-pidpriemtsiv. URL: http://zakon1.rada.gov.ua/laws/show/z0341-06/page (accessed:5.06.19).

Стаття поступила:24.12.2019 